\title{
MODELLING ANALISIS STANDAR BELANJA DALAM KEWAJARAN ANGGARAN (STUDI EMPIRIS PADA PEMERINTAH DAERAH KABUPATEN WAJO DI SULAWESI SELATAN)
}

\author{
Rasyidah Nadir*, Muhammad Ridwan Arif dan Fatmawati \\ Dosen pada Jurusan Akuntansi Politeknik Negeri Ujung Pandang \\ *rrasyidah_nadir@yahoo.co.id
}

DiPublikasi: 01/01/2020

http://dx.doi.org/10.22225/kr.11.2.1255.100-109

\begin{abstract}
This study aims to examine the application of the Shopping Standards Analysis (ASB) model to the City / Regency governments in South Sulawesi. Spending standards analysis is an instrument for the assessment of the reasonableness of workload and costs for an activity organized by a local government. The data used in this study are secondary data sourced from the Budget Implementation List (DPA) of 2017 and 2018, 2017 Budget Realization Data from all SKPDs in the local government, and Data Unit Standards based on Regional Regulations (Perda). The method of data analysis uses standard shopping analysis with a linear regression model approach. The ASB model is carried out through three stages of preparation namely the stage of data collection, the stage of equalizing activities, and the stage of forming the model. The research method was carried out using two approaches namely library research and field research.
\end{abstract}

Keywords: Analysis of Shopping Standards, List of Budget Execution, Linear Regression.

\begin{abstract}
Abstrak
Penelitian ini bertujuan untuk mengkaji penerapan model Analisis Standar Belanja (ASB) pada pemerintah Kota/Kabupaten di Sulawesi Selatan. Analisis standar belanja merupakan suatu instrumen untuk penilaian kewajaran atas beban kerja dan biaya terhadap suatu kegiatan yang diselenggarakan pemerintah daerah. Data yang digunakan dalam penelitian ini adalah data sekunder yang bersumber pada Daftar Pelaksanaan Anggaran (DPA) Tahun 2017 dan 2018, Data Realisasi Anggaran 2017 dari seluruh SKPD pada pemerintah daerah setempat, dan data Standar Satuan Harga berdasarkan Peraturan Daerah (Perda). Metode analisis data menggunakan analisis standar belanja dengan pendekatan model regresi linear. Model ASB dilakukan melalui tiga tahapan penyusunan yaitu tahap pengumpulan data, tahap penyetaraan kegiatan, dan tahap pembentukan model. Metode penelitian dilakukan dengan menggunakan dua pendekatan yaitu penelitian kepustakaan (library research) dan penelitian lapangan (field research).
\end{abstract}

Kata kunci: Analisis Standar Belanja, Daftar Pelaksanaan Anggaran, Regresi Linear.

\section{PENDAHULUAN}

Sistem anggaran kinerja pada dasarnya merupakan sistem yang mencakup kegiatan penyusunan program dan tolok ukur kinerja sebagai instrumen untuk mencapai tujuan dan sasaran program. Anggaran dengan pendekatan kinerja sangat menekankan pada konsep value for money dan pengawasan atas kinerja output (Mardiasmo,2009). Penerapan sistem anggaran kinerja dalam penyusunan anggaran dimulai dengan perumusan program dan penyusunan struktur organisasi pemerintah yang sesuai dengan program yang diusulkan, mencakup pula penentuan unit kerja yang bertanggung jawab atas pelaksanaan program, serta penentuan indikator kinerja yang digunakan sebagai tolok ukur dalam mencapai tujuan program yang telah ditetapkan.

Anggaran dengan pendekatan prestasi kerja merupakan suatu sistem anggaran yang mengutamakan hasil kerja dan output dari setiap program dan kegiatan yang direncanakan. Penyusunan anggaran berdasarkan prestasi kerja pada dasarnya dilakukan sejak pemerintah daerah mengajukan Kebijakan Umum APBD (KUA) dan Prioritas dan Plafon Anggaran Sementara (PPAS) harus ditentukan secara tegas mengenai besaran hasil dan outputnya. Namun, penyusunan anggaran berdasarkan prestasi kerja akan terlihat secara operasional pada saat SKPD mengajukan RKA-SKPD. Untuk mengimplementasikan anggaran berdasarkan prestasi kerja, pemerintah daerah perlu melengkapi instrumen seperti capaian kinerja, indikator kinerja, analisis standar 
belanja, standar satuan harga, dan standar pelayanan minimal.

Istilah Analisis Standar Belanja (ASB) diperkenalkan dalam Undang-Undang No.32 Tahun 2004 tentang Pemerintah Daerah. Analisis Standar Belanja (ASB) mempunyai maksud dan istilah yang sama dengan Standar Analisa Belanja (SAB). Selanjutnya, peraturan perundangundangan yang mendasari ASB yaitu Peraturan pemerintah No.58 Tahun 2005 tentang Pengelolaan Keuangan Daerah, yang dijabarkan lebih lanjut dalam Permendagri No.13 Tahun 2006 tentang Pedoman Pengelolaan Keuangan Dearah. Dalam regulasi-regulasi tersebut disebutkan bahwa ASB merupakan salah satu instrumen pokok dalam penganggaran berbasis kinerja. Namun, ASB yang diamanatkan dalam regulasi-regulasi tersebut belum menunjukkan secara riil dan operasional tentang ASB sehingga ASB menjadi sesuatu yang abstrak bagi pemerintah daerah di Indonesia.

Ketidakadaan wujud ASB secara riil pada pemerintah daerah menimbulkan berbagai macam masalah dalam penyusunan APBD. Masalah klasik dalam penyusunan APBD diantaranya penentuan anggaran dilakukan secara incremental yaitu penentuan besaran anggaran hanya dengan menambah atau mengurangi jumlah rupiah pada item-item anggaran yang telah ada sebelumnya dengan menggunakan data-data tahun sebelumnya sebagai dasar dan tidak ada kajian yang mendalam terhadap data anggaran tersebut, penentuan anggaran dipengaruhi oleh 'NAMA' kegiatan dan oleh 'SIAPA' yang mengajukan anggaran (Ritonga, 2010).

Penelitian terdahulu yang mengkaji penerapan ASB belum banyak dilakukan sementara pemerintah daerah dalam mengimplementasikan anggaran berbasis kinerja perlu melengkapi instrumen analisis standar belanja dalam penyusunan anggaran. Penelitian mengenai evaluasi, implementasi model ASB telah dilakukan oleh beberapa peneliti sebelumnya seperti Putra (2012) mengevaluasi penganggaran daerah dengan analisis ASB di Kabupaten Ngawi, penelitian Fatikhah (2013) membuat model ASB pemerintah kota Batu, dan penelitian Amaliah (2015) membuat model ASB pada pemerintah kabupaten Bulukumba.

Atas dasar penelitian terdahulu maka peneliti melakukan penelitian mengenai kajian pembuatan model analisis standar belanja pada beberapa kegiatan yang sama di SKPD pemerintah daerah
kabupatenWajo tahun anggaran 2017. Penelitian ini berbeda dengan penelitian sebelumnya, dalam penetapan model ASB peneliti akan membuat model analisis standar belanja pada beberapa kegiatan pada pemerintah daerah kabupaten. Hal ini dilakukan untuk mendapatkan gambaran apakah beberapa kegiatan yang sama pada SKPD di pemerintah daerah kabupaten Wajo telah memenuhi kewajaran anggaran belanja dan pengalokasian anggaran yang dilakukan secara ekonomis, efisien dan efektif.

Penyusunan ASB sangat penting dilakukan pada pemerintah daerah termasuk pemerintah daerah kabupaten wajo karena dalam penganggaran keuangan daerah sering ditemukan berbagai masalah yaitu: (1) kesulitan untuk menilai kewajaran beban kerja atas suatu kegiatan sejenis antar program/kegiatan dan antar SKPD; (2)dalam proses penyusunan dan penentuan anggaran menjadi suatu hal yang bersifat subjektif; (3) adanya ketidakadilan dalam mengalokasikan besaran anggaran untuk dua atau lebih kegiatan yang sama; (4)aparat pemerintah daerah tidak memiliki argumen yang kuat jika "dituduh" melakukan pemborosan, dan (5) proses penyusunan anggaran sering kali tertunda dan membutuhkan waktu yang lama. Hal-hal tersebut menjadikan konsep ASB sangat penting diterapkan dalam pemerintah daerah.

Konsep ASB masih sangat jarang diterapkan pada pemerintah daerah provinsi, kota, dan kabupaten di seluruh Indonesia karena masih sangat sedikit referensi yang mengacu pada konsep ASB sehingga masih banyak daerah yang belum mengetahui proses penyusunan ASB. Penelitian-penelitian yang terkait ASB juga masih jarang dilakukan. Hal ini yang mendorong peneliti untuk melakukan penelitian dengan mengkaji penerapan model Analisis Standar Belanja (ASB) pada beberapa kegiatan/program yang sama di SKPD Pemerintah Kabupaten Wajo. Pemilihan pemerintah daerah kabupaten Wajo karena Pemerintah daerah ini cukup berhasil dalam pengelolaan keuangan daerah dan berkomitmen untuk melaksanakan penganggaran berbasis kinerja. Namun, penerapan konsep ASB dalam penyusunan anggaran berbasis kinerja belum digunakan, Instrumen yang digunakan dalam penyusunan anggaran pada pemerintah daerah kabupaten Wajo hanya menggunakan standar harga satuan dan standar biaya umum. Sehingga sangat penting buat peneliti mengkaji suatu model Analisis Standar Belanja yang sesuai dengan karakteristik pelaksanaan kegiatan/ 
program di pemerintah kabupaten Wajo.

Target temuan dalam penelitian ini adalah memberikan kontribusi dalam bentuk pembuatan model analisis standar belanja pada pemerintah daerah kabupaten Barru dan Wajo. Model analisis standar belanja oleh pemerintah daerah setempat dapat digunakan pada proses penyusunan APBD sebagai suatu instrumen dalam menilai kewajaran anggaran beberapa kegiatan yang sama pada setiap SKPD, dan diharapkan dengan model analisis belanja yang akan dibuat dapat dijadikan suatu acuan dalam kebijakan penyusunan anggaran pemerintah daerah kabupaten Wajo.

Secara umum ada tiga pendekatan dalam menentukan pola perilaku belanja. Ketiga pendekatan itu adalah pendekatan intuisi, pendekatan analisis enjinering, dan pendekatan analisis data belanja masa lalu (Ritonga, 2010).

Berdasarkan hasil penelitian mengenai kajian analisis standar belanja pemerintah kota Batu (Fatikhah, 2012) yang menunjukkan bahwa penggunaan ASB pada pemerintah kota Batu dapat menentukan kewajaran belanja, meminimalisasi terjadinya pengeluaran yang kurang jelas yang mengakibatkan inefisiensi anggaran, meningkatkan efisiensi dan efektivitas dalam pengelolaan keuangan daerah, menentukan anggaran berdasarkan pada tolok ukur kinerja yang jelas, dan unit kerja mendapat keleluasaan yang lebih besar untuk menentukan anggarannya sendiri.

Putra (2012) dalam penelitiannya mengenai Evaluasi Penganggaran Keuangan Daerah dengan Analisis Standar Belanja Tahun anggaran 2010 (studi kasus: Badan Perencanaan Pembangunan Daerah kabupaten Ngawi) menghasilkan model regresi linier sederhana dengan ASB, menghitung nilai minimum dan maksimum anggaran belanja, serta menghitung prosentase alokasi belanja pada masing-masing objek belanja. Berdasarkan prosentase alokasi belanja diketahui bahwa kegiatan koordinasi di Badan Perencanaan Pembangunan kabupaten Ngawi, diketahui 40\% pelaksanaan anggaran keuangannya dalam kondisi underfinance, $20 \%$ wajar dan $40 \%$ overfinance.

Oktaria (2012) dalam penelitiannya mengenai analisis kendala-kendala penerapan ASB (Studi kasus pada kabupaten Katingan-Kalimantan Tengah) menunjukkan hasil bahwa analisis standar belanja yang telah disusun ternyata sudah tidak relevan lagi untuk dipergunakan dalam praktek penganggaran di kabupaten Katingan. Hal ini terlihat dari uji-t berpasangan (paired sample $\mathrm{t}$ -test) yang dilakukan mendapatkan bahwa tidak terdapat perbedaan antara anggaran yang dihitung tanpa dan dengan menggunakan ASB. Faktor yang menyebabkan hal itu antara lain adalah karena perubahan kebijakan belanja yang terjadi di tahun anggaran berikutnya yang tidak dapat diakomodir oleh ASB yang telah ada. Selain itu juga perilaku anggaran di kabupaten Katingan dinilai masih belum mampu menerapkan anggaran berbasis kinerja. Oleh sebab itu, selain diperlukan revisi terhadap rumusan ASB yang ada, juga diperlukan perubahan perilaku anggaran yang mendukung terciptanya anggaran berbasis kinerja.

Hasil penelitian lainnya menunjukkan bahwa kebutuhan anggaran berdasarkan pengembangan analisis standar belanja dari dua belas jenis kegiatan bimbingan teknis kabupaten Kuningan tahun anggaran 2008 terjadi overfinancing yang tidak cukup signifikan. Namun jika dilihat dari objek belanja terdapat ketidakwajaran pengalokasian anggaran biaya pada rincian belanja dari beberapa kegiatan di setiap satuan kerja perangkat daerah. Komponen belanja yang dimaksud adalah belanja honorarium non PNS, belanja material, belanja makanan dan minuman, dan belanja perjalanan dinas. Seluruh rincian belanja tersebut ditemukan adanya inefisiensi alokasi anggaran, penetapan volume beban kerja yang tidak efektif, serta adanya alokasi anggaran yang tidak sesuai dengan penetapan standar harga (Narulita, 2009).

\section{METODE}

Penelitian ini menggunakan metode penelitian deskriptif dengan jenis penelitian studi kasus. Penelitian dilakukan pada kabupaten Wajo. Jenis data yang digunakan adalah data sekunder berupa Dokumen Pelaksanaan Anggaran (DPA) tahun 2017 dari keseluhan SKPD pada pemerintah daerah kabupaten Wajo, data Realisasi Anggaran 2017, serta data Standar Satuan Harga. Metode pengumpulan data diperoleh melalui observasi secara langsung untuk memperoleh informasi tentang penyusunan anggaran belanja pada masing-masing SKPD dan bagaimana bagian keuangan mendapat laporan dari seluruh SKPD secara tepat waktu, melalui wawancara pada bagian perencanaan dan keuangan untuk memperoleh keterangan tentang penentuan anggaran yang ada dalam dokumen RKA dan DPA, melalui Focussed Group Discussion (FGD) 
untuk penentuan kegiatan, dan melalui dokumentasi yaitu dengan memperoleh data sekunder RKA/DPA, Realisasi Anggaran dan Standar Satuan Harga.

Penyusunan analisis standar belanja dilakukan dengan tiga tahapan, yaitu tahap pengumpulan data, tahap penyetaraan kegiatan, dan tahap pembentukan model. Pada tahap pengumpulan data, kegiatan SKPD harus dikumpulkan secara bersama untuk memperoleh gambaran awal atas berbagai jenis kegiatan yang terjadi pada pemerintah daerah. Semua data (populasi) SKPD harus dilibatkan sehingga dapat memenuhi kerangka konseptual penyusunan ASB yaitu asumsi demokrasi. Data yang dikumpulkan pada tahap ini adalah DPA dan data realisasi anggaran. ke dalam jenis atau kategori kegiatan yang memiliki kemiripan pola kegiatan dan bobot kerja yang sepadan. Artinya, kegiatan yang bobot pekerjaannya sama maka akan dikelompokkan pada golongan atau kelompok yang sama. Tahapan ini dilakukan untuk memenuhi kerangka konseptual yang pertama, yaitu penyusunan ASB harus berdasarkan prinsip anggaran berbasis kinerja.

Tahap ketiga merupakan tahap pembentukan model, model yang dibentuk untuk memperoleh gambaran nilai belanja dan alokasi yang terjadi di pemerintah daerah. Strategi kegiatan penelitian ini tergambar dari ketiga mekanisme tahapan pembentukan model analisis standar belanja.

\section{III.PELAKSANAAN KEGIATAN}

Pelaksanaan kegiatan ini akan dilakukan dalam dua tahapan yaitu yang diperoleh dari tahap pengumpulan data

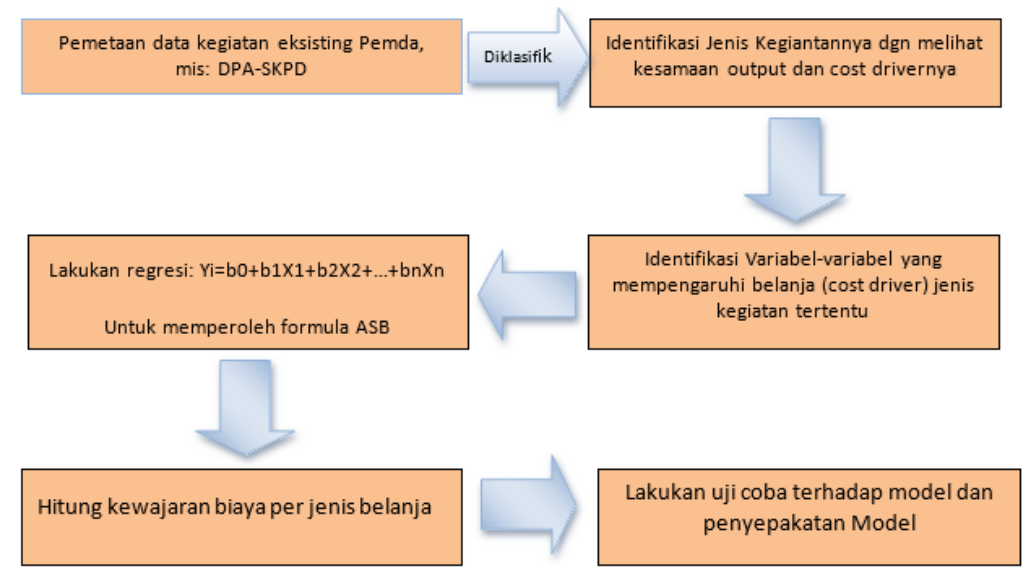

Gambar 1 Langkah Inisiasi Analisis Standar Belanja (ASB) Sumber: Yanse (2016)

Tahap1 : Observasi dan wawancara

Tahap ini, peneliti melakukan dua aktivitas lapangan yaitu pra observasi dan observasi, tahapan ini ditekankan pada pengenalan peneliti terhadap objek/sasaran penelitian, pengenalan terhadap aktivitas objek peneliti yaitu pengelola keuangan daerah di setiap SKPD.

Tahap 2: Pengumpulan Data

Tahap ini merupakan tahap lanjutan. Data yang diperoleh melalui observasi dapat dijadikan acuan dalam penyusunan ASB, dengan tujuan agar ASB yang tersusun berdasarkan aturan perundang-undangan yang jelas serta memiliki kaitan hukum. Data dasar yang dijadikan sebagai dokumen sumber berupa DPA SKPD selama 1 (satu) tahun terakhir dan standar satuan harga. 


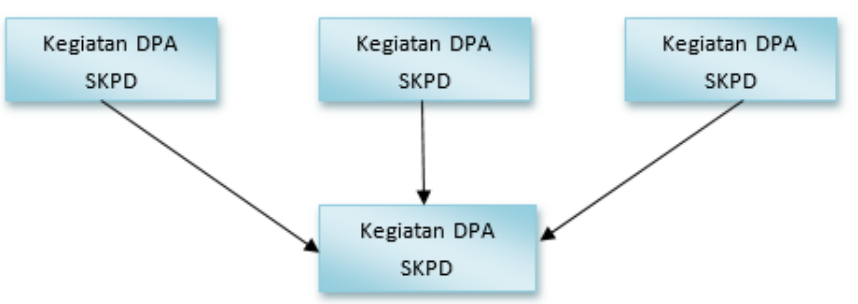

Gambar 2 Skema Input Data

Tahap 3: Identifikasi kegiatan yang menjadi komponen anggaran SKPD

Dari data SKPD Kabupaten untuk tahun anggaran dilakukan input data dari masingmasing kegiatan atas program yang sudah direncanakan dan akan diperoleh database kegiatan. Hanya program dan kegiatan yang sejenis dan relevan yang akan diinput.

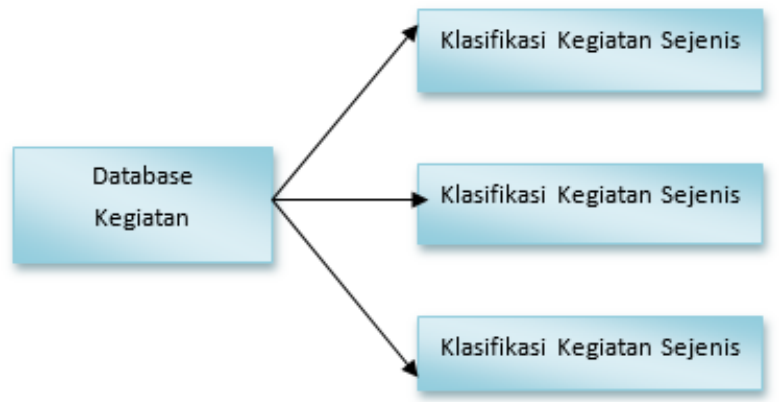

Gambar 3 Skema Klasifikasi Kegiatan

Tahap 4: Pembentukan Model ASB, tahapan ini terdiri atas:

Penentuan dan pengelompokkan aktivitas yang sejenis dari masing-masing kegiatan SKPD

Penentuan standar belanja dan anggaran kebutuhan belanja

Memasukkan aktivitas dan anggaran kebutuhan belanja ke dalam formulir perhitungan ASB. Tujuan dari pembuatan tabel format perhitungan untuk memisahkan berupa nominal belanja tetap (fixed cost) dan nominal belanja variabel (variabel Cost)

Penentuan range nilai ASB dan belanja ratarata per kegiatan

Penentuan batasan belanja rata-rata ASB

Model dan format analisis standar belanja.

Tahap 5: uji coba pembuatan model analisis standar belanja

Tahap 6: Penyempurnaan/revisi model analisis standar belanja

Tahap 7: Implementasi model analisis standar belanja

Tahap 8: Kesimpulan

\section{IV.HASIL DAN PEMBAHASAN}

Penyusunan ASB melalui beberapa tahap, tahap pertama dimulai dengan mengumpulkan data sekunder Daftar Pelaksanaan Anggaran (DPA) SKPD tahun anggaran 2017 dan Realisasi Anggaran 2017 berupa kegiatan eksisting pemerintah daerah yang disesuaikan dengan data kegiatan Permendagri No. 13 Tahun 2006. Data DPA 2017 dan data realisasi anggaran pada pemerintah kabupaten Wajo diperoleh dari keseluruhan SKPD sejumlah 53 (lima puluh tiga) SKPD yang terdiri dari 29 dinas, 7 badan, 2 sekretariat, 1 inspektorat, dan 14 kecamatan. Dari 53 SKPD diidentifikasi setiap kegiatan tentang input dan outputnya. Selanjutnya menentukan kegiatan-kegiatan yang akan dibuatkan Analisis Standar Belanja (ASB) yaitu beberapa kegiatan yang terbanyak dianggarkan oleh SKPD dengan input kegiatan yang jelas dan terukur. Kegiatan yang dimaksud adalah kegiatan penyusunan laporan.

Masing-masing kegiatan tersebut dikelompokkan dan dikumpulkan dalam kegiatan yang sejenis yang diselenggarakan di tahun anggaran berjalan 2017 yang memiliki kesamaan output dan cost drivernya menjadi satu 


\begin{abstract}
kelompok ASB, lalu diberikan penamaan kelompok ASB tersebut. Adapun tahap penyusunan ASB sebagai berikut:
\end{abstract}

\section{Tahap pengumpulan data}

Tahapan pertama penyusunan ASB adalah mengumpulkan data sekunder berupa DPA SKPD tahun 2017, data SKPD yang ada sebanyak 53 (lima puluh tiga) sesuai dengan jumlah SKPD yang ada di pemerintah kabupaten Wajo. Data SKPD kemudian diidentifikasi input dan pengendali belanja (cost driver) dari masingmasing kegiatan. Selanjutnya menentukan kegiatan-kegiatan yang ada akan dibuat ASB, yaitu dari beberapa kegiatan yang memiliki input dan pengendali belanja kegiatan yang jelas dan terukur.

Tahap penyetaraan kegiatan

Tahap penyetaraan kegiatan dilaksanakan setelah tahapan pengumpulan data ke dalam kategori kegiatan yang memiliki pola kegiatan dan bobot kerja yang setara. Kegiatan yang dimaksud dalam penelitian ini adalah ASB penyusunan laporan pada Pemerintah daerah Wajo. Kegiatan ASB penyusunan laporan merupakan ASB yang dibentuk dari penyetaraan kegiatan yang sejenis dan relevan yaitu kegiatan Penyusunan Renja SKPD, Penyusunan LAKIP SKPD, Penyusunan Perencanaan Anggaran SKPD, Penyusunan RENSTRA SKPD, Penyusunan Laporan Keuangan Semesteran, Penyusunan Laporan Realisasi Semester I dan Prognosis 6 Bulan Berikutnya, Laporan Capaian Kinerja dan Ikhtisar Realisasi Kinerja SKPD, Penyusunan Laporan Keuangan akhir Tahun SKPD, dan Penyusunan Laporan Keuangan Pemerintah Daerah.

Kegiatan penyusunan laporan pada SKPD pemerintah kabupaten Wajo diadakan di semua SKPD dan memiliki anggaran yang bervariasi antara satu SKPD dengan SKPD lainnya. Pemicu dari kegiatan ini adalah jumlah dokumen yang dihasilkan dan jumlah orang dalam tim penyusun laporan. Kegiatan tersebut dianggarkan oleh 53 (lima puluh tiga) SKPD dari 53 (lima puluh tiga) SKPD yang ada.

Jumlah seluruh anggaran kegiatan penyusunan laporan sebesar $\mathrm{Rp}$ 2.284.327.450,- dengan jumlah pemicu/pengendali belanja dokumen dan orang adalah 3113 dokumen/orang. Terdapat 181 kegiatan yang sejenis dan relevan, kegiatan dengan jumlah alokasi anggaran paling besar adalah kegiatan penyusunan laporan yang dilaksanakan oleh Badan Pengelola Keuangan dan Aset Daerah (BPKAD) sejumlah Rp 257.350.000,- dengan pengendali belanja 36 dokumen/orang. Adapun kegiatan dengan alokasi anggaran terendah adalah kegiatan penyusunan laporan dilaksanakan oleh kecamatan Tanasitolo dengan jumlah anggaran $\mathrm{Rp} 2.000 .000$,- dan jumlah pengendali belanja 4 dokumen/orang.

Tahap pembentukan model

Pada tahap pembentukan model ASB meliputi penentuan nilai belanja tetap, belanja variabel, dan penentuan pengendali belanja dari tiap-tiap jenis kegiatan dengan menggunakan regresi linear dengan bantuan aplikasi SPSS. Setelah itu dilakukan perhitungan batas minimum belanja, batas maksimum belanja, perhitungan rata-rata belanja, dan persentase perhitungan alokasi. Hubungan antara SKPD, Kegiatan, Anggaran, dan Pengendali Belanja pada Kegiatan penyusunan laporan. Berdasarkan data anggaran belanja dan pengendali belanja, maka dibuat suatu model pengujian koefisien regresi kegiatan penyusunan laporan. Hasil pengujian regresi linear kegiatan penyusunan laporan keuangan menunjukkan nilai $\mathrm{R}$ Square sebesar 0,57 atau $57 \%$ dengan Sig $=0,001$. Secara statistik angka ini menunjukkan hasil yang baik karena nilai signifikansi yang disyaratkan lebih kecil dari 5\%. Dengan demikian, dapat disimpulkan bahwa variabel jumlah dokumen dan orang (cost driver) yang merupakan variabel independen dalam penelitian ini secara bersama-samaberpengaruh terhadap variabel dependen yaitu total anggaran. Hal ini berarti jika terjadi kenaikan jumlah dokumen dan orang maka berpengaruh terhadap kenaikan anggaran.

Pembentukan model analisis standar belanja didasarkan pada hasil regresi dengan membentuk rumusan formula ASB yaitu terdiri dari belanja total, belanja tetap, belanja variabel dan cost driver (Jumlah dokumen dan jumlah orang). Model ASB penyusunan laporan yang telah terbentuk dapat digunakan untuk menentukan belanja rata-rata yaitu sebesar Rp 12.620.594,Atas dasar hasil perhitungan besaran belanja ratarata, maka dapat ditentukan nilai batas belanja minimum dan batas belanja maksimum masingmasing sebesar $\mathrm{Rp} \mathrm{0,-} \mathrm{untuk} \mathrm{belanja} \mathrm{minimum}$ dan Rp 30.432.350,- untuk belanja maksimum. Nilai batas belanja minimum dan belanja maksimum dapat digunakan sebagai acuan dalam menilai kewajaran dari anggaran yang diajukan setiap SKPD, dan dapat juga digunakan sebagai 
acuan dalam penentuan realisasi anggaran.

Tahapan selanjutnya adalah perhitungan persentase alokasi, baik untuk alokasi rata-rata, alokasi batas atas, dan alokasi batas bawah. Alokasi merupakan proporsi sebuah obyek belanja dalam suatu kegiatan. Rata-rata adalah proporsi rata-rata dari obyek belanja tersebut untuk seluruh SKPD di Pemerintah Kabupaten Wajo. Batas bawah adalah proporsi terendah dari obyek yang bersangkutan sedangkan batas atas adalah proporsi tertinggi dari obyek tersebut. Berdasarkan hasil perhitungan yang ditunjukkan dalam tabel pendokumentasian/pembentukan ASB, ditemukan bahwa honor panitia pelaksana memiliki alokasi belanja rata-rata tertinggi sebesar 42,53\%. Hal ini disebabkan karena sebagian besar kegiatan penyusunan laporan mengganggarkan obyek belanja ini dengan jumlah yang cukup tinggi. Untuk alokasi batas bawah, semua obyek belanja memiliki presentase alokasi batas bawah sebesar 0\%. Hal ini berarti obyek belanja tersebut tidak bisa dianggarkan apabila dibutuhkan dalam kegiatan penyusunan laporan. Obyek belanja dengan alokasi dengan alokasi rata-rata terendah adalah Belanjalembur non PNS, hal ini karena tidak semua kegiatan menganggarkan obyek belanja ini.

Pendokumentasian/pembentukan

ASB merupakan tahapan akhir dalam penyusunan ASB. Tahapan ini mendesain format Asb agan dapat memberikan pengendali/pemicu belanja sekaligus memberikan fleksibilitas kepada penggunanya. Pengendali belanja ditunjukkan dengan adanya rumusan formula untuk menentukan pagu total belanja suatu kegiatan berdasarkan target kinerja tertentu dan jumlah macam obyek belanja yang diperkenankan. Adapun fleksibilitas ditunjukkan dengan adanya batas atas dan batas bawah dalam menentuka besaran obyek belanja. Model ASB untuk Kegiatan Penyusunan Laporan ditunjukkan Tabel ASB-01 Penyusunan Laporan.

Penelitian terdahulu dilakukan oleh Amaliah (2015) dengan judul Model Analisis Standar Belanja (ASB) dan Kewajaran Anggaran di Pemerintah Kabupaten Bulukumba, menunjukkan hasil bahwa model ASB kegiatan sosialisasi/ penyuluhan/pelatihan yang dihasilkan adalah $\mathrm{Y}=$ 8.637.625,793+202.423,465X, Model ASB kegiatan penyusunsn pelaporan SKPD yang dihasilkan adalah $\mathrm{Y}=3.259 .976,529+7.330 .594,92 \mathrm{X}$, model ASB kegiatan pemeliharaan rutin/berkala mobil jabatan yang dihasilkan adalah $\mathrm{Y}=1.323 .155,218+14.346 .823,36 \mathrm{X}, \quad$ dari 143 kegiatan untuk 3 (tiga) kelompok ASB hanya 8 (delapan) kegiatan yang overfinance $(5,56 \%)$ dan 1 (satu) kegiatan yang underfinance $(0,69 \%)$. Selebihnya 134 kegiatan (93,75\%) anggarannya wajar. Penelitian lebih lanjut dilakukan oleh Putra (2012) dengan judul Evaluasi Penganggaran Keuangan Daerah dengan Analisis Standar Belanja (ASB) Tahun Anggaran 2010 (Studi Kasus: Badan Perencanaan Pembangunan Daerah Kabupaten Ngawi). Hasil penelitiaan menunjukkan ASB untuk anggaran belanja kegiatan forum komunikasi atau koordinasi Bappeda Kabupaten Ngawi adalah $\mathrm{Y}=9.417 .170,19+203.298,09 \mathrm{X}$. Berdasarkan persentase alokasi belanja diketahui bahwa terdapat $40 \%$ kegiatan yang pelaksanaan anggaran keuangannya dalam kondisi underfinance, $20 \%$ dalam kondisi wajar, dan $40 \%$ dalam kondisi overfinance.

Gambar 3.3 Skema Klasifikasi Kegiatan

\section{KESIMPULAN}

Berdasarkan hasi dan pembahasan yang telah maka dapat ditarik suatu kesimpulan sebagai berikut:

Model ASB untuk kegiatan penyusunan laporan adalah $\mathrm{Y}=2.652 .616,617+579.570,781$ ( Jumlah Dokumen x Jumlah Orang). Adapun masing-masing jumlah belanja rata-rata, belanja maksimum, dan belanja minimum untuk kegiatan ini adalah $\mathrm{Rp} 12.620 .594, \mathrm{Rp} 30.432 .350$, dan $\mathrm{Rp}$ 0 ,-. Model analisis standar belanja berfungsi sama seperti dokumen penganggaran yang digunakan Pemda dalam penyusunan anggaran yaitu dokumen SPM, KUA, PPAS, dan Standar Satuan Harga. ASB juga merupakan salah satu syarat dari indikator penerapan anggaran berbasis kinerja agar kegiatan yang terlaksana diyakini berjalan efektif, efisien dan ekonomis.

Bagi pemerintah kabupaten Wajo, sebaiknya menggunakan analisis standar belanja dalam proses penganggaran untuk menilai tingkat kewajaran besaran anggaran, hal ini diperlukan untuk menghindari kemungkinan overfinance yang dapat membebani anggaran maupun underfinance yang dapat menyebabkan kegiatan yang dilaksanakan tidak dapat berjalan maksimal karena kurangnya anggaran. 


\section{Model ASB Kegiatan Penyusunan Laporan}

\section{ASB-01 PENYUSUNAN LAPORAN}

\section{Deskripsi ASB}

Kegiztan Penyusunan Laporan adalah guatu kegiatan yang dilaksanakan dalam rangka menyusun sebuah laporam atau dukumen (seperti renja SKPD, Lakip SKPD, laporan keuangan semeateran, laporan keuangan akhir tahun, laporan capaian kinerja SKPD dan laporan lainnya) yang dilaksanakan secara rutin dan berkala untuk kepentingan SKPD.

Pengendali belanja (cost atriver)

Jumlah Dokumen dan Jumlah Orang.

Satuan Pengendali belanja tetap (fxed cost):

$=\operatorname{Rp} 2.652 .616,617$ per kegiatan

Satuan pengendali belanja variabel (variable cost) :

Rp 579.570,781 per dokumen per orang

Rumusan ASB (Y = a + blXl)

Belanja Tetap + Belanja Varizbel

$\mathrm{Rp} 2.652 .616,617+(\operatorname{Rp} 579.570,781 \times$ jumlah dolkumen $x$ jumlah orang)

Rentang Relevan:

Jumlah dokumen antara 1 sampai 2

Jumlah Orang dalam tim antara 4 sampai 15

\begin{tabular}{|l|r|r|r|}
\hline \multicolumn{1}{|c|}{ Rincian Belanja } & Batas Bawah & Rata-rata & \multicolumn{1}{c|}{ Batas Atas } \\
\hline Honor Panitia Pelaksana & 0 & 42,53 & 126,01 \\
\hline Honor Non PNS & 0 & 13,85 & 48,74 \\
\hline Lembur PNS & 0 & 6,39 & 27,76 \\
\hline Lembur Non PNS & 0 & 3,98 & 29,03 \\
\hline Belanja Barang Habis Pakai & 0 & 11,46 & 40,37 \\
\hline $\begin{array}{l}\text { Belanja Cetak dan } \\
\text { Penggandaan }\end{array}$ & 0 & 8,14 & 24,42 \\
\hline $\begin{array}{l}\text { Belanja Makanan dan } \\
\text { Minuman }\end{array}$ & 0 & 13,66 & 58,13 \\
\hline
\end{tabular}

\section{DAFTAR PUSTAKA}

Amaliah, A.N. 2015. Model Analisis Standar Belanja (ASB) dan Kewajaran Anggaran di Pemerintah Kabupaten Bulukumba. Tesis. Makassar: Fakultas Ekonomi dan Bisnis Universitas Hasanuddin.

Bastian, Indra. 2010. Akuntansi Sektor Publik. Edisi Ketiga. Jakarta: Erlangga.

Fadilah, Sri. 2009. "Activity Based Costing (ABC) sebagai Pendekatan Baru Untuk Menghitung Analisis Standar Belanja (ASB) dalam Penyusunan Anggaran Pendapatan Belanja Daerah (APBD)". Jurnal Telaah dan Riset Akuntansi, 2(1), Hal 54-78.

Fatikhah, D.N. 2012. Kajian Analisis Standar Belanja Pemerintah Kota Batu. Skripsi. Malang: Fakultas Ekonomi Universitas Ekonomi Universitas Brawijaya Malang.

Mahmudi. 2015. Manajemen Kinerja Sektor Publik. Jakarta: UPP STIM YKPN
Mardiasmo. 2009. Akuntansi Sektor Publik. Yogyakarta: ANDI

Murtin, Alek. 2013. Optimalisasi Peran Analisis Standar Belanja dalam Penyusunan Anggaran Belanja SKPD di Kabupaten Lingga. Makalah Seminar. Kabupaten Lingga: Pemda Kabupaten Lingga.

Narulita, Sari. 2011. Penerapan Konsep Analisa Standar Belanja pada Penyusunan Anggaran Kegiatan Bimbingan Teknis di Kabupaten Kuningan. Tesis. Yogyakarta: Fakultas Ekonomika dan Bisnis Universitas Gadjah Mada.

Oktaria, Benny. 2012. Analisis Kendala-Kendala Penerapan Analisis Standar Belanja (ASB) (Studi Kasus pada Kabupaten Katingan - Kalimantan Tengah). Tesis. Yogyakarta: Fakultas Ekonomika dan Bisnis Universitas Gadjah Mada.

Peraturan Menteri Dalam Negeri Nomor 13 Tahun 2006 tentang Pedoman Pengelolaan Keuangan Daerah. 
2006. Jakarta: Kementerian Dalam Negeri.

Peraturan Menteri Dalam Negeri Nomor 37 Tahun 2014 tentang Pedoman Penyusunan Anggaran Pendapatan dan Belanja Daerah tahun 2015.

Peraturan Menteri Dalam Negeri Nomor 59 Tahun 2007 tentang Perubahan atas Peraturan Permendagri No.13 Tahun 2006 tentang Pedoman Pengelolaan Keuangan Daerah.

Peraturan Pemerintah Nomor 105 Tahun 2000 tentang Pengelolaan dan Pertanggungjawaban Keuangan Daerah

Peraturan Pemerintah Nomor 58 Tahun 2005 tentang Pengelolaan Keuangan Daerah.

Putra, Rahadiyan Prasana. 2012. Evaluasi Penganggaran Keuangan Daerah dengan Analisis Standar Belanja (ASB) Tahun Anggaran 2010. Tesis pada Fakultas Ekonomi Universitas Sebelag Maret: Tidak diterbitkan

Ritonga, Irwan Taufiq. 2010. Analisis Standar Belanja: Konsep, Metode Pengembangan, dan Implementasi di Pemerintah Daerah. Yogyakarta: Sekolah Pascasarjana UGM.

Suwitoadi, Achyuni. 2016. Implementasi ASB pada Penganggaran Daerah (RKA-SKPD). Materi Pelatihan Penganggaran Berbasis Value for Money (Kinerja). Yogyakarta: Program Magister Ekonomika Pembangunan FEB UGM.

Undang-Undang Nomor 22 Tahun 1999 tentang Pemerintah Daerah

Undang-Undang Nomor 25 Tahun 1999 tentang Perimbangan Keuangan Pemerintah Pusat dan Daerah.

Undang-Undang Nomor 32 Tahun 2004 tentang Pemerintah Daerah

Yanse, Kardias. 2016. Konsep dan Implementasi Analisis Standar Belanja (ASB) dalam Perencanaan Anggaran Daerah. Materi Pelatihan Penganggaran Berbasis Value for Money (Kinerja). Yogyakarta: Program Magister Ekonomika Pembangunan FEB UGM. 